\title{
Turban shells of Andrew Bay in Rakhine coastal region of Myanmar
}

\begin{abstract}
Turban shells on intertidal and subtidal areas in Andrew Bay are composed of 12species belonging to genus Turbo Linnaeus 1758 of family Turbinidae falling under the order Archaeogastropoda collected from field observation in 2014, were identified, using liquidpreserved materials and living specimens in the field, based on the external characters of shell structures. The specimens comprised Turbo argyrostomus Linnaeus, 1758, T. articulatus Reeve, 1848, T. bruneus (Röding, 1798), T. chrysostomus Linnaeus, 1758, T. cidaris Gmelin, 1791, T. cinereus Born, 1778, T. crassus Wood, 1828, T. fluctuosus Wood, 1828, T. imperialis Gmelin, 1791, T. intercostalis Menke, 1846, T. petholatus Linnaeus, 1758 and T. radiatus Gmelin, 1791. The distribution of turban shells in intertidal and subtidal zone of Andrew Bay was studied in brief. Moreover, the habitats and utilization of turban shells found along the Andrew Bay were also described.
\end{abstract}

Volume 8 Issue 2 - 2019

\section{Naung Naung Oo, Zarni Ko Ko, Khin Myo Myo Tint}

Assistant Lecturer, Department of Marine Science, Mawlamyine University, Myanmar

\begin{abstract}
Correspondence: Naung Naung Oo, Assistant Lecturer, Department of Marine Science, Mawlamyine University, Mon State, Myanmar, Email naungnaungoomarine@gmail.com
\end{abstract}

Received: April 23, 2019 | Published: April 30, 2019

Keywords: Andrew bay, distribution, habitats, rakhine coastal region, turban shells, utilization

\section{Introduction}

The Turbinidae are tropical gastropods with the majority of species found in the Indo-pacific region; only ten species are present in the Western Central Pacific. ${ }^{1}$ There are 2 genera, Astralium and Turbo and 10 species, namely A. calcar (Linnaeus, 1758); T. argyrostomus Linnaeus, 1758; T. bruneus (Röding, 1798); T. chrysostomus Linnaeus, 1758; T. cinereus Born, 1778; T. coronatus Gmelin, 1791; T. crassus Wood, 1828; T. marmoratus Linnaeus, 1758; T. petholatus Linnaeus, 1758 and T. setosus Gmelin, 1791 in the family Turbinidae. In this region, the turban shells, Turbo Linnaeus, 1758 is probably the most important genus of this family. Many authors have reported significant variations in spatial and temporal distribution and abundance of some species within this family. ${ }^{2,3}$ These species normally present in large numbers, particularly within the shallow near-shore rocky substrate and coral reef ecosystem. ${ }^{4-9}$

In Myanmar, there were currently very few studies dealing with the biology and ecology of these species except taxonomic work of Soe Thu 10. There are 9 species of Turbo, namely T. petholatus reevei Phillippi, 1844; T. argyrostomus Linnaeus, 1758; T. chrysostomus Linnaeus, 1758; T. cornutus Lightfoot, 1786; T. excellens Sowerby, 1855; T. marmoratus Linnaeus, 1758; T. cinereus Born, 1778; T. porphyrites Gmelin, 1791 and T. intercostallium Menke, 1829 (T. intercostalis Menke, 1846) had been reported from the three Coastal Regions of Myanmar. ${ }^{10}$ Likewise, 2 species of Turbo, namely $T$. argyrostomus Linnaeus, 1758 and T. cinereus Born, 1778 had been reported by Naung Naung $\mathrm{Oo}^{11}$ based on morphological and some ecological features collected from various coastal areas of Mon State.

Much information such as their distribution pattern, habitat preferences and habitat range were still remained unknown. The objective of the current study was to determine the spatial variations in abundance of turban shells population in their natural habitat. This information is very important for conservation and for better management of this species.

\section{Materials and methods}

Some turban shells were collected in the forms of drift and live specimens living in intertidal and shallow subtidal areas such as Geik Taw, Pearl I., Thanban Gyaing, Abae Chaung, Thanbayar Gyaing, Mayoe Bay, Kathit I., Thabyu Gyaing, Ponenyat Gyaing, Kwinwine Gyaing, Kyauk pone gyi hmaw and Maung shwe lay Gyaing around the Andrew Bay, Rakhine State (Figure 1) during the field trip in 2014.

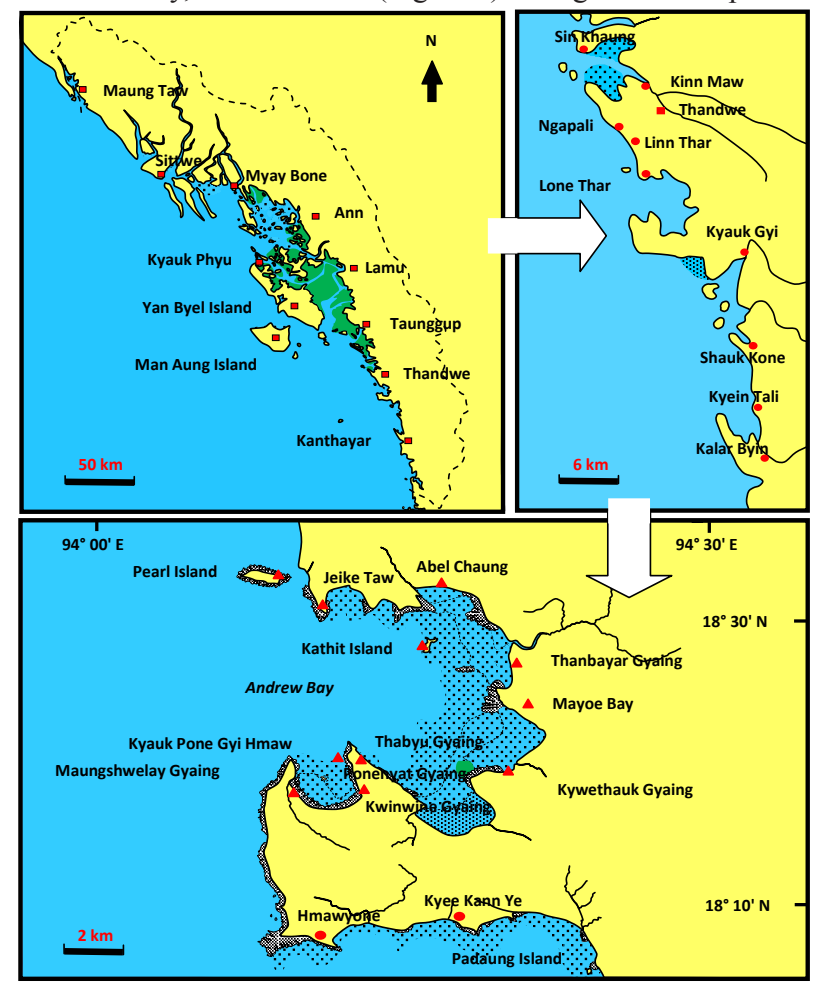

Figure I Map showing the collection sites of Andrew Bay in Rakhine Coastal Region. 
All collections were preserved in $10 \%$ formalin in seawater. The epifaunas were removed by soaking the shells in a solution of caustic soda and then cleaned, washed, dried, and ready for storage, they are lightly rubbed with a small amount of oil applied with a brush to make them fresh-looking in a slight luster to the surface, and aid in presenting the delicate colouring for further study.

All voucher specimens were deposited at the Museum of the Department of Marine Science, Mawlamyine University (MLM.MS). Zoogeographical distribution of each species was prepared with the data from the literature available. Ecological notes and associated species of these molluscs were also recorded in the field.

\section{Results and discussion}

The spatial variations in abundance of turban shells surveys conducted from 12 collection sites at Andrew Bay and its vicinity

Table I Systematic of turban shells in Andrew Bay, Rakhine Coastal Region in Rakhine Coastal Region. In this study, a total of 12species of turban shells were observed from different habitats at intertidal and shallow sublittoral zones, to a depth of about $20 \mathrm{~m}$ or more. This systematic account follows the identifying set out by Poutiers et.al in detailed $^{1,3,12-19}$ (Table 1)(Figure 2).

Shells are thick, often heavy, turbinate to conical (occasionally flattened) in shape. Outer sculpture is very variable, often spiral to nodular. Periostracum well developed to absent. Aperture is variously rounded, without a siphonal canal, nacreous inside. Inner lip is smooth. Umbilicus present, at least at juvenile stages. Operculum is strongly calcified externally, its inner layer corneous, usually showing spiral coiling with a subterminal or central nucleus. Head with a short, midventrally split snout, and a pair of long tentacles, the eyes on stalks at their outer bases. Foot is large and ovate, sometimes anteriorly truncate, with a fleshy ridge on either side bearing tentaculate processes.

\begin{tabular}{|c|c|c|}
\hline \multicolumn{3}{|c|}{ Phylum: Mollusca Linnaeus, I758 } \\
\hline \multicolumn{3}{|c|}{ Class: Gastropoda Cuvier, I795 } \\
\hline \multicolumn{3}{|c|}{ Order: Archaeogastropoda Thiele, 1925} \\
\hline \multicolumn{3}{|c|}{ Family: Turbinidae Rafinesque, 1815} \\
\hline \multicolumn{3}{|l|}{ Genus: Turbo Linnaeus, I 758} \\
\hline Species & Common Name & Local Name \\
\hline T. argyrostomus Linnaeus, I 758 & Silver mouth turban & Ngwe-nar-jay \\
\hline T. articulatus Reeve, 1848 & Articulated turban & Jay/ Kha-yu-tha-di \\
\hline T. bruneus (Röding, I798) & Brown Pacific turban & Jay/ Kha-yu-tha-di \\
\hline T. chrysostomus Linnaeus, 1758 & Gold mouth turban & Shwe-nar-jay \\
\hline T. cidaris Gmelin, |79| & Crown turban & Jay-chaw \\
\hline T. cinereus Born, I778 & Smooth moon turban & Jay-chaw \\
\hline T. crassus Wood, I 828 & Crass turban & Kyauk-sein-jay \\
\hline T. fluctuosus Wood, 1828 & Wavy turban & Jay/ Kha-yu-tha-di \\
\hline T. imperialis Gmelin, I79I & Green turban & Kyauk-sein-jay \\
\hline T. intercostalis Menke, I846 & Ribbed turban & Jay/ Kha-yu-tha-di \\
\hline T. petholatus Linnaeus, I 758 & Tapestry turban & Kyaung-myat-lone \\
\hline T. radiatus Gmelin, I79| & Rayed dwarf-turbun & Jay-sue \\
\hline
\end{tabular}

Turban shells mainly living in shallow waters of warm temperate and tropical seas, especially on rocky and coral reef habitats. The local distribution and habitat of each turban species are shown in Table 2 and 3. These are herbivorous animals, feeding on small epibenthic algae and vegetable detritus. Turbans (especially the larger species) are commonly collected in the Indo-West Pacific, both for their edible flesh and nacreous shell. They are locally valued for food and some are sought for mother-of-pearl or for carving ornaments. Green turban, Turbo marmoratus Linnaeus, 1758 with massive shells possessing shiny iridescent pearl layers, used in the manufacture of buttons, lamp-shades and other fancy articles, support fisheries of importance in Myanmar. ${ }^{20,21}$

Collected locally for food and shell craft on the Indochinese peninsula. In seaside villages of Japan, children put the operculum in vinegar because it makes a circular movement as it gradually dissolves. ${ }^{1}$ Turban shell support an important recreational fishery along the Andrew Bay that provides income for small businesses such as bait and tackle shops, restaurants, hotels, boat rental shops, marinas, and many others. The shells are found on the submerged rocky or coral reefs at moderate depths. In recent years, heavy commercial exploitations have locally depleted populations. Efforts are expected in the future to produce juveniles in hatcheries and introduce turbans in areas in which they have become extinct or areas currently poor in fisheries resources.

The distribution of turban shells presented by the data from the 12 collection sites of intertidal to subtidal rock and reef areas in Andrew Bay is that abundance is moderate. This is particularly true when it is considered that the 12 sites were spread over a wide area in a region known for high biodiversity. In the present study, Kyauk pone gyi hmaw site had higher abundance than other 11 collection sites. A total of 12species of turban shells were recorded with their habitats of which 10species in Kyauk pone gyi hmaw; 8species in Kathit Island, Ponenyat Gyaing and Kwinwine Gyaing; 7species in Pearl Island and Maung shwe lay Gyaing; 6species in Geik Taw and Thabyu Gyaing; 5 species in Abae Chaung and Thanbayar Gyaing; and 4species in Thanban Gyaing and Mayoe Bay, respectively (Table 2). 

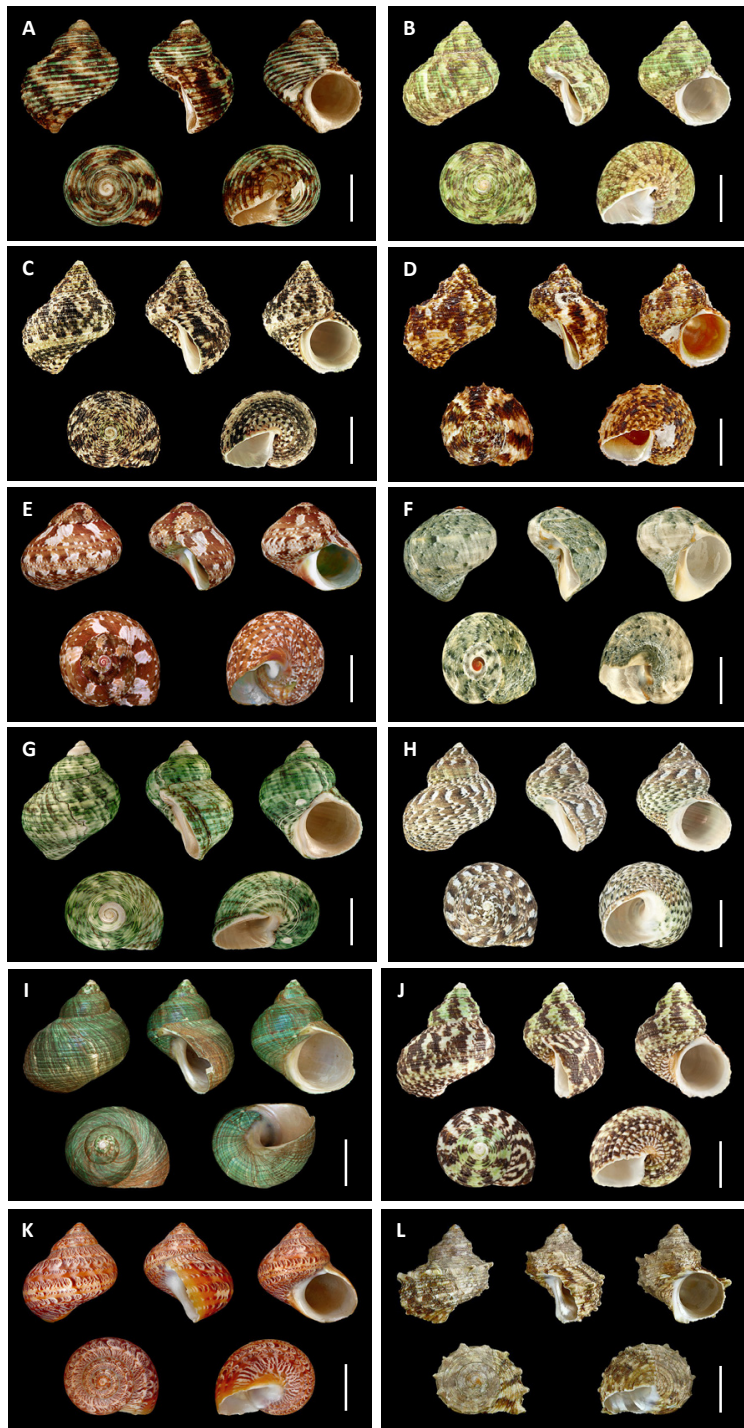

Figure 2 Turban shells: (A) Turbo argyrostomus Linnaeus, 1758. (B) T. articulatus Reeve, 1848. (C) T. bruneus (Röding, 1798). (D) T. chrysostomus Linnaeus, 1758. (E) T. cidaris Gmelin, I79I. (F) T. cinereus Born, I778. (G) T. crassus Wood, I828. (H) T. fluctuosus Wood, I828. Scale bars=I20mm. Turban shells: (I) Turbo imperialis Gmelin, I79I,( J) T. intercostalis Menke, I846, (K) T. petholatus Linnaeus, 1758, (L) T. radiatus Gmelin, 179I. Scale bars=120mm.

Table 2 Distribution of turban shells in Andrew Bay, Rakhine Coastal Region

\begin{tabular}{|c|c|c|c|c|c|c|c|c|c|c|c|c|}
\hline \multirow[b]{2}{*}{ Sampling site } & \multicolumn{12}{|c|}{ Recorded species } \\
\hline & 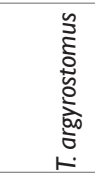 & 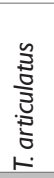 & 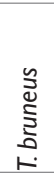 & 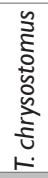 & 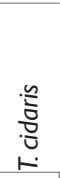 & 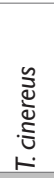 & 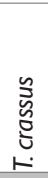 & 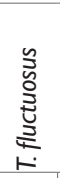 & 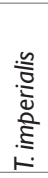 & 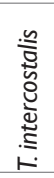 & 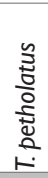 & 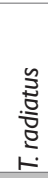 \\
\hline \multicolumn{13}{|l|}{ Geik Taw } \\
\hline \multicolumn{13}{|l|}{ Pearl I. } \\
\hline \multicolumn{13}{|l|}{ Thanban Gyaing } \\
\hline \multicolumn{13}{|l|}{ Abae Chaung } \\
\hline \multicolumn{13}{|l|}{ Thanbayar Gyaing } \\
\hline \multicolumn{13}{|l|}{ Mayoe Bay } \\
\hline \multicolumn{13}{|l|}{ Kathit I. } \\
\hline \multicolumn{13}{|l|}{ Thabyu Gyaing } \\
\hline \multicolumn{13}{|l|}{ Ponenyat Gyaing } \\
\hline \multicolumn{13}{|l|}{ Kwinwine Gyaing } \\
\hline Kyauk pone gyi hmaw & & & & & & & & & & & & \\
\hline Maung shwe lay Gyaing & & & & & & & & & & & & \\
\hline
\end{tabular}

Citation: Naung NO, Zarni KK, Tint KMM. Turban shells of Andrew Bay in Rakhine coastal region of Myanmar.J Aquac Mar Biol. 2019;8(2):63-67. DOI: I0.15406/jamb.2019.08.00244 
Table 3 Habitat of turban shells in Andrew Bay, Rakhine Coastal Region

\begin{tabular}{|c|c|}
\hline Species & Habitat \\
\hline T. argyrostomus & Coral reef areas, in moderately exposed habitats and in lagoons of atolls. \\
\hline T. articulatus & $\begin{array}{l}\text { Under slabs and stones and in caverns of the outer edge of coral reefs. In well- } \\
\text { aerated waters, from low in the intertidal zone to shallow sublittoral depths. }\end{array}$ \\
\hline T. bruneus & Rocky shores and coral reefs, in shallow subtidal waters to a depth of about $20 \mathrm{~m}$. \\
\hline T. chrysostomus & In coral reef areas. Intertidal and shallow sublittoral zones, to a depth of about $20 \mathrm{~m}$. \\
\hline T. cidaris & In exposed areas of coral reefs. Sublittoral zone, in shallow water. \\
\hline T. cinereus & Common among rocks or gravel. \\
\hline T. crassus & Near reefs, in shallow subtidal water, mainly at depths of I to $5 \mathrm{~m}$. \\
\hline T. fluctuosus & $\begin{array}{l}\text { On reef substrate under corals and blocks. Shallow subtidal water to a depth of } \\
\text { about } 20 \mathrm{~m} \text {. }\end{array}$ \\
\hline T. imperialis & $\begin{array}{l}\text { In subtidal, coral reef areas open to a constant flow of clean oceanic water. Juveniles } \\
\text { mainly living on reefs crests, at depths of I to } 5 \mathrm{~m} \text {; adults also occurring deeper on } \\
\text { slopes, to about } 20 \mathrm{~m} \text { or more. }\end{array}$ \\
\hline T. intercostalis & On rocky shores and coral reefs. Intertidal and shallow subtidal waters. \\
\hline T. petholatus & $\begin{array}{l}\text { Shallow coral reefs and rocky shores, in relatively protected habitats. Sublittoral, to } \\
\text { depths of about } 40 \mathrm{~m} .\end{array}$ \\
\hline T. radiatus & Among rocks and gravel, or in crevices. Intertidal. \\
\hline
\end{tabular}

\section{Conclusion}

Many aspects of the shell morphology in turban shells are associated with physical stabilization in diverse ecological settings. Shells are moderately large, solid and heavy, turbinate in shape with length usually greater than width. Spire is well developed, pointed, whorls strongly convex and with angular shoulders. Outer sculptures are variable, with rounded, unequal spiral cords and many fine scaly axial threads, most developed on the interstices of cords. Operculum is nearly circular in outline, with a sub central nucleus and a convex, smooth external surface. Outside of shell is variable in colour and pattern. The distribution of turban shells in Andrew Bay moderately disperses along the shallow coral reefs and rocky shores. Local people frequently collected by Turbinidae in the area, mainly for food. The operculum is well known in shell jewellery under the name "cat's eye".

\section{Acknowledgments}

I am indebted to Dr Aung Myat Kyaw Sein, Acting Rector of Mawlamyine University and Dr Mie Mie Sein, Pro-Rector of Mawlamyine University, for their encouragement and supports in preparing this work. I am very grateful to Dr San Tha Tun, Professor and Head of the Department of Marine Science, Mawlamyine University, for his valuable suggestions and constructive criticisms on this study. I would like to express my sincere thanks to colleagues of Andrew Bay Observation Group, Department of Marine Science, Mawlamyine University, for their kindly help me in many ways during field trips. Many thanks go to Daw Lwin Lwin, Retired Lecturer of the Department of Marine Science, Mawlamyine University, for her assistance in preparations of the manuscript. I would like to thank my beloved parents, U Win Maung and Daw Than Than Aye, for their physical, moral and financial supports throughout this study.

\section{Conflicts of interest}

The author declares that there are no conflicts of interest in relation to this article.

\section{References}

1. Poutiers JM. Gastropods. In: Carpenter KE, Niem VH, editor. FAO Species Identification Guide for Fishery Purposes. The Living Marine Resources of the Western Central Pacific. Volume 1. Seaweeds, Corals, Bivalves and Gastropods. Food and Agriculture Organization, Rome. 1998. p. 363-649.

2. Pilsbry HA. Monograph of the Turbinidae and Trochidae: family Turbinidae. In: Tryon Jr GW, Editor. Manual of conchology; structural and systematic. With illustrations of the species. Volume 10, Part 2, Philadelphia, Academy of Natural Sciences. 1888. p.161-323.

3. Hickman CS, Mclean JH. Systematic revision and suprageneric classification of trochacean gastropods. Sci Ser nat Hist Mus. 1990;35:1169.

4. Kimani EN. The Larval Development and Juvenile Growth of the Silver Mouth Turban, Turbo argyrostomus. Unpublished MSc Thesis, Department of Marine Science, The graduate school of the University of the Ryukyus. 1996. 
5. Kojima S, Segawa R, Hayashi I. Genetic differentiation among population of the Japanese turban shell Turbo (Batillus) cornutus corresponding to warm currents. Mar Ecol Prog Ser. 1997;150:149-155.

6. Kurihara T, Shikatani M, Nakayama K, et al. Proximate Mechanisms Causing Morphological Variation in a Turban Snail Among Different Shores. Zoolog Sci. 2006;23(11):999-1008.

7. Martone RG, Micheli F. Geographic variation in demography of a temperate reef snail: importance of multiple life-history traits. Mar Ecol Prog Ser. 2012;457:85-99.

8. Tan SK. Colour forms of the tapestry turban snail in Singapore waters Singapore Biodiversity Records. 2014;2013:148-149.

9. Tan SK and Low MEY. A record of the green turban Turbo marmoratus in Singapore. Singapore Biodiversity Records. 2013; 2013:102-103.

10. Soe Thu. Taxonomy and distribution of Burmese marine gastropods. Unpublished MSc Thesis, Department of Zoology, Art and Science University, Rangoon. 1980. 530 p.

11. Naung Naung Oo. Study on the marine gastropods from Mon coastal areas. Unpublished MRes Thesis. Department of Marine Science, Mawlamyine University. Myanmar. 2012. 360 p.

12. Kyaw Myint. Check list of Molluscs of the Mergui Archipelago and the Moscos Islands. University Education Journal. 1971;6(2):37- 48.
13. Tantanasiriwong R. An illustrated checklist of marine shelled gastropods from Phuket Island, adjacent mainland and offshore Islands, western Peninsular Thailand. Bull Mar Biol Cent. Phuket, Thailand. 1978. 21: $1-22$.

14. Abbott RT. Seashells of Southeast Asia. Graham Brash. Singapore. 1991. $145 \mathrm{p}$.

15. Carpenter A. Population of the spider conch from Indo-pacific region. $J$ Mar Biol Ass. UK. 2002;11:51-76.

16. Dance SP. Shells. Dorling Kindersley, Inc. New York; 2002. 256 p.

17. Subba Rao NV. Indian Seashells (Part-I): Polyplacophora and Gastropoda, Rec. zool. Surv. India, Occ. 2003. Paper No. 192: i-x, 1-416. (Published: Director, Zool. Surv. India, Kolkata)

18. Oliver APH. Guide to sea shells of the world. Philip's a division of Octopus Publishing Group Ltd, London. 2004. 320 p.

19. http://www.marinespecies.org. 2019.

20. Soe Thu. Sea shells of Ngapali. University Education Journal. 1970;5(1):317-368

21. Soe Thu. Sea shells of Maungmagan. University Education Journal. 1971;6(2):397-432. 